\title{
The Performance of Pictorialist Dance Photography
}

Vedel, Karen

Published in:

Nordic Theatre Studies

DOI:

$10.7146 /$ nts.v29i1.103314

Publication date:

2017

Document version

Publisher's PDF, also known as Version of record

Document license:

CC BY

Citation for published version (APA):

Vedel, K. (2017). The Performance of Pictorialist Dance Photography. Nordic Theatre Studies, 29(1), 138-161. https://doi.org/10.7146/nts.v29i1.103314 


\title{
The Performance of Pictorialist Dance Photography
}

\section{KAREN VEDEL}

\begin{abstract}
Looking to the widely disseminated pictorialist photos of Waldemar Eide (Norway) and Henry B. Goodwin (Sweden) featuring the Russian ballerina Vera Fokina and the Swedish ballerina Jenny Hasselquist, the article is an enquiry into the role of the dancer in the pictorialist studio and the contribution of pictorialist photography to the turning point when the aesthetics of dance was being reconsidered, the dancing body reconfigured, and photography emerged into an art form in its own right. Taking inspiration from the socio-material approach of photography historian Elizabeth Edwards, the analysis downplays the question of content in favor of a focus on the material practices in the photographic studio at the level of the photographer as well as the dancer-model posing before the camera. Placed within a discourse of new materialism, performance and performativity, it moreover considers the resulting photos as material objects that perform in continuing processes of meaning production. An example of the latter discussed at the end of the text is Harald Giersing's abstract painting 'The Dancer' based on a photo of Jenny Hasselquist as The Dying Swan.
\end{abstract}

\section{KEYWORDS}

Dance pictorialism, modern ballet, material practices, Vera Fokina, Jenny Hasselquist, Mikhail Fokine, Waldemar Eide, Henry B. Goodwin, Harald Giersing. 


\section{The Performance of Pictorialist Dance Photography}

\section{INTRODUCTION}

Pictorialist photos of Russian and Russified dance artists in the Nordic countries in the early twentieth century have always struck me as intriguing in historiographic terms. In art history generally, pictorialism is often cast as a failure and a steppingstone for what became conceived as real modernist photography. ${ }^{1}$ Moreover, in line with the tradition of celebrity artist portraiture, the widely circulated pictorialist photos of star dancers from around the turn of the nineteenth and twentieth century have been associated with popular culture. By the same standards, the predominant adjectives attributed to pictorialism, such as sentimental, feminized and derivative, are familiar aversions of modernism that were disavowed, or rather 'purged' in favor of the straight photography that followed. ${ }^{2}$

The photos to which I turn my attention here hold all of the above qualities. Predominantly featuring female dancers posing in costumes from works by renowned choreographer and ballet reformist Mikhail Fokine, ${ }^{3}$ they strike painterly notes of neo-classicism and orientalist enigma, enhanced by diffuse light and smudged edges, fading the motif into the background. However, to the dance historian, they also point to shifts in the corporeal aesthetics of dance and similar shifts in the photographic representation of the dancers' bodies that suggest a two-way relationship whereby photography served the dance(r) and the dance( $r$ ) served photography in manners that are not immediately discernible.

Drawn to this enigma, my paper intertwines two questions. One asks about the role of the dance(r) in the pictorialist studio, the other about the contribution of the resulting photos to the turning point when the aesthetics of dance was being reconsidered, the dancing body re-configured, and photography

1. The position of pictorialism in art history is discussed by among others Armstrong 1998, 48-50 and Rancière 2013.

2. Armstrong 1998, 52.

3. In the Latin alphabet, the name is spelled in various other ways, e.g. Mikhail Fokin (DK) or Michel Fokine (US). 
emerged into an art form in its own right. Structuring my argument around these questions, the paper starts with a literature review and a brief outline of the theoretical framework. Next, follows an introduction to the defining characteristics of pictorialism as well as the dance historical context of the activities of the celebrated Russian ballerina, Vera Fokina and her husband, Mikhail Fokine, in 1918-1919. Then, I dive more deeply into the archival material relating to a studio session involving Vera Fokina and photographer Waldemar Eide in Stavanger, Norway, and juxtapose this information with the account of a studio session with photographer Henry B. Goodwin in Stockholm.

Rather than consider the results merely in terms of content, my analysis takes a socio-material approach that combines several analytical perspectives: One looks behind the photographic objects to the interrelations between those involved in bringing them about. Another looks at the material practices whereby the resulting images were produced, re-produced and circulated in exhibitions and journals. In continuation, I trace the journey of one particular photo from the photographer's studio over exhibitions and publications to a cubist-inspired painting by the early Danish modernist, Harald Giersing, from 1919.

Earlier archival research at the Royal Library in Copenhagen, the Royal Danish Theatre Archives and Library, and the Danish National Archives revealed source material relating to the activities of Fokine and Fokina in Denmark between 1918-1919. ${ }^{4}$ A relatively dark hole in Fokine's career, it was also a chapter in the history of Danish theatre dance that had not yet been studied in any depth. My curiosity about the link between the practitioners of the reformed Russian ballet, pictorialism and modernist aesthetics became re-ignited with the well-researched publication accompanying Stavanger Kunstmuseum's exhibition on Waldemar Eide curated by Vibece Salthe in 1916. The catalogue features reproductions of 14 from a total of 15 photos from his Vera Fokina portfolio from 1919, only a few of which were known to me beforehand. ${ }^{5}$ The accompanying articles provide a wealth of information about the photographer, the context of his practice and artistic outlook, as well as a more detailed understanding of pictorialist photography that has helped focus this paper. ${ }^{6}$ For instance, Hanne Holm-Johnsen's contribution, "Waldemar Eide and Pictorialism", which pointed me to Nordisk Tidskrift för fotografi [Nordic Journal for Photography] with articles on pictorialism and Henry B. Goodwin's review of Eide's work. Adding to this, I found a small tributary book on the Swedish ballerina Jenny Hasselquist from the series Publikens Gunstlingar (1918) authored by Ida Goodwin and richly illustrated with her husband, Henry B. Goodwin's

4. Vedel 2008, 126-98.

5. The last photo in the Vera Fokina Portfolio shows Mikhail Fokine. E-mail from Vibece Salthe to the author 22 September 2017.

6. The exhibition entitled Waldemar Eide - Photography and Art opened at Stavanger Art Museum on 27 October 2016 and ran until 19 February 2017.

7. Holm-Johnsen 2016, 87-92. 
dance photos. Written for a general audience, the essay includes an account of sessions in the photographer's studio 1916-1918 with Hasselquist posing before the camera in the repertoire of Fokine. ${ }^{8}$ Additional research has brought to light new material in, among other archives, the Michel Fokine Papers in the Harvard Theatre Collection, to which I shall return below. ${ }^{9}$

In addition to the photos of Fokina and Hasselquist in the above-mentioned booklet, I rely on the reproduction of Eide's photos in the catalogue from 2016 and for the part of Goodwin, on postcards and photos reproduced in Danish theatre journals (e.g. Teatret) and ladies' weekly magazines (e.g. Vore Damer). When these and other photos are discussed below, more precise details will be provided.

\section{LITERATURE REVIEW}

Dance photography in the early decades of the twentieth century has interested scholars across a range of disciplines. A review of the literature points to overlapping subgenres including celebrity portraiture, dance photography as well as photos of nude and semi-nude models. My reading has focused on the discussion of the role of dancers in pictorialist photography.

Noting the obvious, literary scholar Nancy Armstrong in her article, "Modernism's Iconophobia and What It Did to Gender", reminds us that celebrity portraiture in the Victorian age depended on the willingness of famous people to pose before the photographer. ${ }^{10}$ In a similar manner, dance photography depended on the willingness of the dancers and their performance before the camera. Writing on the history of photo-secessionism, William A. Ewing draws a line from the popular business cards of dancers used as collectors' items in the 1860s over the post-card sized photographs at the end of the century, to the studio portraits that followed. Ewing suggests that the larger and more artificially styled photos from the early twentieth century opened the possibility of achieving the goals of both dancer and photographer. ${ }^{11}$ Media and dance scholar, Judith B. Alter, however, questions the extent to which this potential was realized. In her analysis of the role of photography in books by dancer-writers from the same era, she criticizes the photo-secessionists ${ }^{12}$ for continuing to idolize the dancer and failing to convey the power and vitality of their dancing. Commenting on the collaboration between dancers and pictorialist photographers, she writes: "(F)rom the dancer's side of the partnership, the photographs record more about the dancers' appearances, costumes, and charac-

8. Goodwin and Goodwin 1918.

9. The correspondence belonging to the Fokine Collection was identified through the Online Archival Search Information System of Harvard University Library and made accessible to me as digital scans.

10. Armstrong 1998, 56.

11. Ewing's reference is to the collaboration between Vaslav Nijinsky and Baron Adolf De Meyer around L'Après-midi d'un Faune (1912). Ewing 1987, 21.

12. Photo-secessionism is the American term for pictorialism. 
teristic poses, than they reveal about the dancing."13 By way of contrast, Judith $B$. Alter notes that the dancer-writers, whose instructive dance books are the focus of her own analysis, took advantage of "both the beauty and utilitarian feature of the sister art of photography."14

Included in the material analysed for this paper are photos where the fascination with Vera Fokina's costumes is unquestionable. On the whole, however, I argue that they communicate a materiality, which has as much to do with the dancer's command of her corporeal presence before the camera as it has to do with the contrasts between the tactility of textiles and previously unseen amounts of bared flesh and skin. In this respect, I tend to agree with theatre scholar Karl Toepfer who notes a shift in dancers' understanding of photography around 1910 from a technology primarily used for realistic documentation to a technology that was much more efficient in idealizing their art. $^{15}$ In his discussion of nudity and movement in German body culture 19101935, Toepfer, moreover, suggests that "[t]he emancipatory authority of modern dance achieved its most convincing representation when aligned with the expanding expressive capacity of photographic technology."16 Viewed against not only the idealized body in visual representations of classical ballet but also the ecstatic expressivity of early modern dance, I ascribe a different, but still emancipatory, authority to the corporeal presence of Russified dancers as they appear in pictorialist photography. This reading resonates with dance historian Lynn Garafola's claim that Fokine's contribution to ballet modernism relied on a heightened expressiveness of what she calls, 'the unfettered body' and a 'mimetic of the whole body.'17 Vera Fokina is a key figure in this respect as are several of her female dancer colleagues in the Nordic countries, students of Mikhail Fokine such as Jenny Hasselquist, to whose work before the camera I will return below.

\section{THEORETICAL FRAMEWORK}

The research questions on which I base my study are informed by Jacques Rancière's Aisthesis. Scenes from the Aesthetic Regime of Art (2013), especially his writing on Loïe Fuller's dance in the late nineteenth century and of the American photographer Alfred Stieglitz's photography in the latter part of his career around 1920. Key points from these texts will form part of my discussion below.

In extending the notion of performance to discuss photography, I draw on

13. Alter 1994, 106.

14. Op.cit. 97. Among the artist-writers whose books Alter analyzes are Margaret M'Doubler's Dance and Its Place in Education (1925) and Isadora Duncan's The Art of the Dance by Sheldon Cheney (ed.) (1928).

15. Toepfer 1997, 374.

16. Ibid.

17. Garafola 1989, 38 . 
Roland Barthes' Camera Lucida. Reflections on Photography $(2000)^{18}$, in which he discusses the historical links between photography and painting on the one hand and between photography and theatre on the other. In continuation of Barthes' observation that "Pictorialism" is only an exaggeration of what the Photograph thinks of itself," 19 he suggests that the emergence of photography owes more to discoveries in chemistry than to painting. To Barthes, however, the approximation of photography to art is most clearly expressed in its relation to theatre: "Photography is a kind of primitive theater, a kind of Tableau Vivant, a figuration of the motionless and made-up face beneath which we are the dead." ${ }^{20}$ The figure of death is here observed as an intermediary that - not unlike the momentary stillness before the camera - frames the simultaneous presence and absence of the actor. Having established a link between theatre and photography, Barthes names the involved the Operator, the Subject and the Spectator. In line with the reference to the historical genre of tableaux vivants, he sees 'the pose' as defining the nature of photography: "The physical duration of this pose is of little consequence; [...] for the pose is not, here, the target or even a technique of the Operator, but the term of an "intention" of reading: looking at that photograph I inevitably include in my scrutiny the thought of that instant, however brief, in which a real thing happened to be motionless before the eye." ${ }^{21}$ The theoretical argument, taken from Barthes, to my consideration of the role of the dancer in the pictorialist studio, is that 'the pose', with its underlying intention, connects the Subject (the dancer) and the Spectator in a manner that bypasses the Operator (the photographer).

Looking to performance studies, I draw on Jon McKenzie's Perform or Else (2001). In his endeavor "to rehearse a general theory of performance"22, McKenzie identifies shared operational characteristics of the disparate realms of culture, organization and technology that, in one way or another, have to do with their ability 'to move and multiply'. ${ }^{23}$ McKenzie acknowledges the centrality of Judith Butler's deconstructive reading of J. L. Austin's theory of speech acts and its extension into the analytical notion of performativity, whereby symbolic systems that include (but are not limited to) theatre can be constructed as objects of inquiry. ${ }^{24}$ In my study of specific instances of dance pictorialism in the early twentieth century, I engage photography as a 'symbolic system' to be studied within an analytical framework that combines the discourses of performance and performativity. I find support for this approach in photography

18. Original in French 1980, English translation 2000.

19. Barthes 2000, 31. Quotation marks in original.

20. Ibid.

21. Op. cit. 78. Quotation marks and italics in original.

22. McKenzie 2001, 88.

23. McKenzie names three paradigms that bridge between performance and performativity: The efficacy of cultural performance, the efficiency of organization and the effectiveness of technology. 2001, 23.

24. Op. cit. 41. 
historian Elizabeth Edwards' writing on photos as material objects that belong in continuing processes of meaning production, exchange, and usage. ${ }^{25}$ While Edwards draws on anthropology's study of material culture in her socio-material approach, the echo of Barthes is implicit as she argues that "photographs should not be understood only through forensic and semantic analysis of content, but as objects that constitute material performances of a complex range of historiographical desires in the negotiation among past, present and future." ${ }^{26}$ Edwards' understanding of the photographic object's ability to perform in human relations ${ }^{27}$ may be read in conjunction with Jane Bennett's writing on new materialism, in which objects - far from being arrested in time and in a stable relation to a given event - are distinguished by their capacity to act or perform as 'vibrant matter'. ${ }^{28}$ Continuing this line of thought, Bennett discusses the notion of 'thing-power' which "name[s] the moment of independence (from subjectivity) possessed by things", that is where things - with a reference to Bruno Latour - become 'actants' in their own right. ${ }^{29}$ The answer to the second part of my question regarding the contribution of dance pictorialism to the shaping of new aesthetics and corporeal configurations takes inspiration from the writing of McKenzie and Bennett, but most of all from Edwards and her socio-material approach.

\section{MATERIAL PRACTICES IN THE PICTORIALIST STUDIO}

Before going deeper into the role of the dancer and how the potential for collaboration (or co-creation) between dancer and photographer was realized in the studios of Goodwin and Eide, I will briefly recap the characteristics of pictorialism drawing on general art historical definitions complemented with more detailed descriptions of the material practices involved. ${ }^{30}$

In the history of photography, pictorialism is roughly dated to a period between the years $1890-1917 .{ }^{31}$ Having been tied not only to the mechanical device of the camera but also to realism, photographers at the end of the nineteenth century, strived to detach their craft from the purely representational in favour of something closer to fine arts. Engaging motifs that spanned from studio portraits to landscapes, and employing a range of different studio practices, pictorialism came to name a movement rather than a well-defined style. Thus, the characteristics are best described as eclectic: They may involve particular optical equipment such as the soft-lens; they often include the careful

25. Edwards 2002, 67.

26. Edwards 2009, 130.

27. Op. cit. 135.

28. Bennett 2010, 3.

29. Ibid.

30. Leaning on among others Ewing 1987, Swedlund 1974 and Söderberg 1988.

31. According to Armstrong, the American photographer Alfred Stieglitz urged photography to divorce from painting already in $1904(1998,50)$. Rancière notes the date of Stieglitz's death certificate to pictorialist photography as $1917(2013,222)$. 
composition of elements within the picture frame and manipulation of the light sources, for instance with soft fabrics such as chiffons. A substantial part of the creative endeavour, however, took place after the work before the camera was finished in the work with the negative and in the printing process, where close attention was paid to the material qualities of the paper, its grain, and surface grading. The manipulation of the negative involved a variety of chemicals, salts, and/or bromoil that allowed a print to be enlarged and also hardened the surface so that it could be worked on further with, for instance, colour pigments. Another popular technique, whereby the print surface was prepared for further crafting by hand, was the application of gum and potassium bichromate. ${ }^{32}$

Contemporary writing on pictorialism is rich with elaborate descriptions of the work with the negative. ${ }^{33}$ In situating the photographer as combined scientist and artist-genius, however, they also limit the space for acknowledging the work before the camera, let alone the pose of the model. Unless a celebrity, the models in pictorialist dance photography were rarely acknowledged by name, nor were they given a voice of their own. A similar point is made by Vibece Salthe, whose research on Waldemar Eide reveals that aside from Vera Fokina and the Norwegian celebrity Lillebil Ibsen, the female models were anonymous in the small but very important part of the photographer's production that consisted of dance photos, nude, and semi-nude photos. ${ }^{34}$ Following the identification of the models in all three subgenres as dancers, Salthe notes that the majority were trained in Fokine's reformed style of movement either by the choreographer himself or by one of his students. ${ }^{35}$ This information is confirmed by my research into the names of the students who studied privately with Fokine in Denmark in 1918. ${ }^{36}$ The fact that all the models fall within the broad category of Russified dancers suggests a privileged connection between female practitioners of the reformed Russian ballet and pictorialist dance photography in the Nordic context.

Reports from art exhibitions with pictorialist photos were shared among colleagues in the Nordic countries already before the turn of the century. ${ }^{37}$ It is, however, commonly agreed that Henry B. Goodwin was an important figure in consolidating an interest in pictorialism with a wider Nordic circle of photographers. ${ }^{38}$ Several interrelated events from the years 1913 and 1914 support this

32. Söderberg and Rittsel 1983, 240-1.

33. See for instance Nordisk Tidskrift för fotografi $1917-21$.

34. Salthe 2016b, 83-4.

35. Op.cit. 82. Salthe identifies the following Norwegian dancers: Ellen (Buttedahl) Sinding and Grethe Rutz-Nissen in addition to the Swedish dancer Ebon Strandin, who had been a member of the Royal Swedish Opera ballet at the time of Fokine's association with the institution in 1913-14.

36. Vedel 2008, 175.

37. Söderberg and Rittsel 1983, 200.

38. Ibid. See also Holm-Johnsen 2016, 87. 
claim. ${ }^{39}$ In 1913 Goodwin arranged a course with his own teacher from Leipzig, the pictorialist photographer Nicola Perscheid for the Swedish Photographer's Society in Uppsala. ${ }^{40}$ The following year, Goodwin himself gave a lecture on pictorialism to the wider Nordic community of photographers assembled in Malmö, and also set up a studio of his own in Stockholm which he named The Pictorial Portrait Studio.

\section{THE FOKINE ENTERPRISE IN THE NORDIC COUNTRIES}

Coinciding with the events that consolidated pictorialism in a Nordic context, Mikhail Fokine became associated with the Royal Swedish Opera ballet in 1913 and 1914. Premiered by Diaghilev's Ballets Russes, the ballets he staged in Stockholm include from March 1913: Cléopâtre (Kleopatra) and Les Sylphides (Sylfiderna), and from January 1919: Carnaval, Spéctre de la Rose (Rosendrömmen) and Schéhérazade (Scheherazade). Among the most widely circulated photos from these ballets is a series showing Vera Fokina and Mikhail Fokine. Signed by Atelier Jaeger ${ }^{41}$ they show the top celebrity dancers of the day in studio in scenes from the repertoire. The enhanced plasticity of the dancer that distinguished Fokine's reformed style is demonstrated in the poise of their bodies and in the emblematic poses in which the dancers' movements have been arrested. Adding to this are the costumes by Léon Bakst; orientalist and richly decorated for Schéhérazade and Cléopâtre, and with a twisted fusion of Biedermeier and Commedia dell'Arte for Carnaval.

My findings suggest that Atelier Jaeger's photos of the Russian celebrities from 1913 and 1914 were effective in communicating Fokine's reforms, repertoire, and style in a Nordic context. In addition to being circulated as postcards, the photos were widely published in the printed media. Featured for instance in the Danish journal Teatret from August 1913 is a photo of Vera Fokina in the title role of Cléopâtre. ${ }^{42}$ The ballerina poses balancing on one leg with the other foot drawn up the shin to just below the knee in a parallel position and the arms stretched over the head with clasped hands. In another rendition from the same ballet, Fokina is on the floor resting on one hip with her legs stretched to the side and the weight of her torso supported on one arm. In a third, she is in the same imploring position with her eyes averted towards Fokine, who

39. Henry B. Goodwin. (1878 Munich - 1931 Stockholm). Given name: Heinrich Karl Hugo Bürgel. Studied photography and also completed a doctoral degree in Nordic languages from the University of Leipzig in 1903. Moved to university position in Uppsala, Sweden in 1905. Left academia in favour of professional photography in 1914 (Söderberg and Rittsel 1983, 242).

40. Portrait photographer Nicola Perscheid developed a soft-focus lens that bears his name (Söderberg and Rittsel 1983, 246).

41. The photographer of the Fokine photos from 1913 and 1914 is Herrmann Sylwander; the owner of the Atelier Jaeger from 1908-1948, whose motifs included scenes and artists from Swedish theatre (op cit. 166 and 268).

42. Teatret, August 1913. 
poses above her as Amoun. Serving as a template for photos from orientalist ballets in the reformed Russian style, the images multiply as the poses are reproduced in studio photos from, for instance, the Royal Danish Ballet's version of Cléopâtre, in Danish entitled En Nat i AEgypten with choreography by Emilie Walbom in $1918^{43}$ and in photos from Cléopâtre with dancers from the Royal Swedish Opera ballet. ${ }^{44}$ This is also reiterated in one of the photos from the Vera Fokina Portfolio, this time with the ballerina in the title role of Salome - The Dance of the Seven Veils. ${ }^{45}$

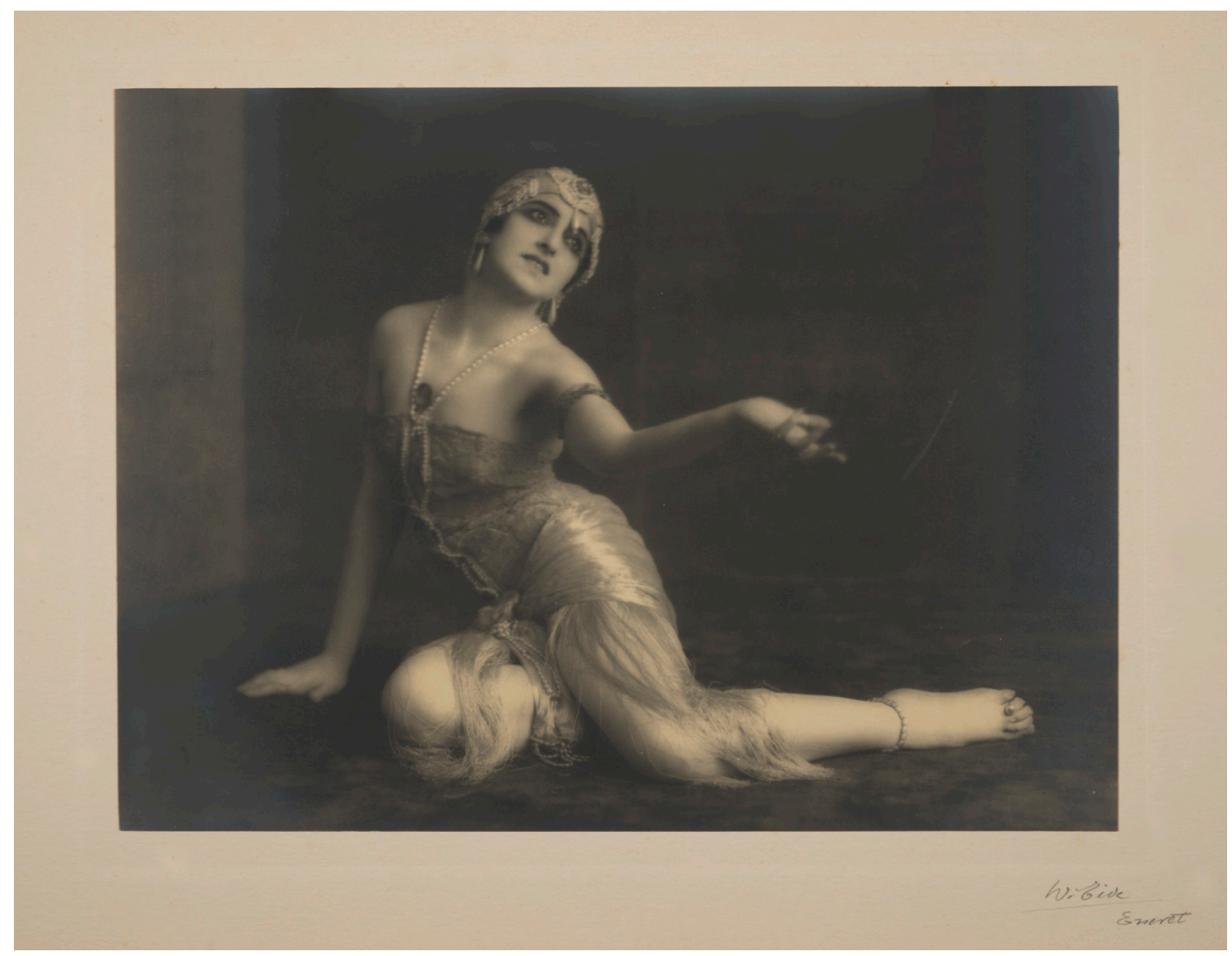

Figure 1. Vera Fokina (1919) Salome - Dance of the Seven Veils. The Vera Fokina Portfolio. Photo by Waldemar Eide, Stavanger Art Museum.

Having definitively broken with Diaghilev's Ballets Russes in 1915, Fokine and Fokina returned to St. Petersburg and choreographic commissions at the Maryinsky Theatre only to leave Russia for good in 1918. According to Cyril W.

43. En Nat i AEgypten premiered on 28 April 1918 by the Royal Danish Ballet. Photographer anon. The Royal Danish Theatre Archives and Library. The choreography of the Danish version was accredited to Emilie Walbom.

44. Rootzén 1945, 97. Anon. Undated.

45. Salthe 2016, 60-61. 
Beaumont's writing on Fokine's ballets from 1935, the couple left St. Petersburg with their son in March 1918 headed for a commission in Stockholm, but were delayed in Turku on account of political unrest in Finland. ${ }^{46}$ As the suitcases were already packed with costumes, arrangements were made instead for a tour of theatres in southern Sweden. ${ }^{47}$ Beaumont's list of performances by Fokine and/or Fokina between 1918 - 1920 is identical with documents in the Fokine Collection at the Harvard Theatre Library. Many of these performances have also been verified from advertisements, debates, and reviews in printed media in Denmark, Sweden, and Norway. According to this list, Fokine and Fokina, after performing in 8 different cities in southern Sweden in April 1918, continued in early May to the Royal Swedish Opera in Stockholm and subsequently played in Norrköping on the way south. When they arrived in Copenhagen to perform on the stage of the Royal Danish Theatre, the general public was already familiar with their names and style through the interest of the printed media including the aforementioned, high quality photos published in illustrated magazines.

The negotiations that landed the couple four guest performances at the Royal Danish Theatre provide a window into the business skills of Fokine. The first telegram, dispatched by an employee from Konserthuset in Göteborg on $4^{\text {th }}$ April, reads: "Will you engage Mikael and Vera Fokin for one evening honorarium 2500 two evenings 4500 three evenings 6000 kroner? Stureson, Koncerthuset." 48 The counter-offer from Copenhagen was to include the performance by the Russian dancers in a larger program for the amount of 1500 DKK for two performances. ${ }^{49}$ After about a month, it was agreed that the Fokines would be billed in a separate program with two guest performances for the fee of 4000 DKK in total. However, a pencil note on the signed contract attests that according to the orders of the theatre director and the initial demands, the final amount paid out after the two performances was 4500 DKK. Thus, at the end of the day, all of Fokine's demands were met. ${ }^{50}$

46. According to Susanne Cartonneau in The International Encyclopedia on Dance, the Fokine family crossed the Baltic on sleds in March 1918 to go to Stockholm where they staged Petrouchka at the Royal Swedish Opera. As there is no record of this production in the theatre's archives, it is my understanding that this production never took place.

47. Archival research in digitalized Finnish newspapers shows that the couple performed in Helsinki in January 1917. This, however, does not preclude that Turku was a stop en route to Sweden. Swedish newspapers confirm that this tour continued to Stockholm (Svenska Dagstidningar online). While there is no evidence of performances by Fokin and Fokina in Turku in 1918, this does not preclude that Turku was a stop en route to Sweden.

48. Telegram dated 4 April. The National Archive. The Royal Theatre. Incoming documents nr. 55. 1918. My translation.

49. Letter (copy) in the journal of the direction of the Royal Danish Theatre. Theatre Journal 71/1918, The Danish National Archives.

50. Contract signed by Mikhail Fokine and Fr. Brockenhuus Schack (Director), The Royal Danish Theater. Date 25 April, 1918. 
Following the performances in Copenhagen, the couple made Denmark their base for the following year and a half. In addition to touring and travelling to do commissioned work, for instance, the outdoor choreography for Barnens Dag in Stockholm in September $1918^{51}$, Fokine made a living for the family teaching private students from the neighboring countries, some of whom later appear in the photos of Goodwin and Eide. Vera Fokina's solo program was premiered in the Odd Fellow Palace in Copenhagen in December 1918, followed by a tour of almost 7 weeks to Norway in February and March 1919 with performances in Kristiania [Oslo], Trondheim, Bergen, and Stavanger. ${ }^{52}$

The research summarized in this section suggests that high quality photos from the repertoire played a central role in, what I call, the Fokine enterprise and moreover that Fokine was a hard negotiator with a strong sense of his own worth. The extensive touring in Sweden and Norway in 1918 and 1919 serve as a contextual backdrop for the sessions in the photographic studios.

I will look at this further in the following section.

\section{WALDEMAR EIDE'S VERA FOKINA PORTFOLIO}

Waldemar Eide's photos of Vera Fokina were created in the wake of the ballerina's performances on tour in Stavanger in March 1919. By presenting them in a portfolio, Eide chose a format that was aligned with the pictorialist imperative of promoting photography as a fine art, where portfolios were used to circulate reproductions of paintings. It was, moreover a format that had previously been used by Alfred Stieglitz, a key figure in photo-secessionism.53

While the precise details of the collaboration before the camera remain undisclosed, three handwritten letters in Russian from tobacconist E. Balabanov in Stavanger to Mikhail Fokine in Copenhagen, provide a glimpse into the negotiations between the choreographer and the photographer. The letters are written over a period of 2.5 months between the studio session and the presentation of the portfolio. ${ }^{54}$ Balabanov acts as a middleman, a fellow Russian in Stavanger, who speaks both languages and can communicate on behalf of Fokine with the Norwegian partners, especially Waldemar Eide. ${ }^{55}$ Contextual information provided in the catalogue from the exhibition of Waldemar Eide's work suggests that Balabanov was by no means the only Russian expatriate in Stavanger in 1919. In the years following World War I and the Revolution in Russia, the city experienced increasing wealth and also enjoyed a rich life of art, music, and theatre. Many artists, both domestic and foreign, would pass

51. According to Aftonbladet the event had 500 performers (15.09.1918). A later issue mentions 800 (20.09.1918). Svenska Dagstidningar.

52. Vera Fokina gave two additional performances on the way back to Copenhagen, one in Uddevalla, Sweden and one in a location listed as Slogelse (sic).

53. Alfred Stieglitz published two portfolios in 1899 and 1900 entitled American Pictorial Photography.

54. Balabanov's letters are dated 15 March, 02 May and 01 June 1919.

55. Danish theatre scholar Annelis Kuhlmann has kindly provided me with a translation of Balabanov's letters from Russian to Danish. 
through Stavanger either on tours that took them up the west coast of Norway or on the way to America or England. ${ }^{56}$ Other Russian celebrities portrayed by Eide in 1918 include the composer-pianist Sergej Rakhmaninov and the ballerina Katharina Fokina, a relative to Mikhail Fokine. ${ }^{57}$ We also learn from Risa that the public display of Eide's photos of celebrities in a showcase on the street was a local attraction in Stavanger with which he not only promoted his own business but also the visiting artists. ${ }^{58}$

Only 9 days after Fokina's last performance in Stavanger in March 1919, Balabanov writes to confirm that he has completed the task of delivering Fokine's 'presentations and photos'59, here taken to mean notes as well as prints from other photo sessions, to Eide. He also informs that the portfolio has already been advertised for sale at a price of 100 NOK apiece and that the first edition of 30 had been sold out before the portfolios were even ready in merely two days. ${ }^{60}$ Six weeks later, Balabanov's second letter addresses the still on-going work in Eide's studio with which there has been some dissatisfaction on behalf of Fokine. Having consulted Eide, Balabanov reassures him that everything has been carried out with precision 'on our side'. The third letter communicates Eide's replies to a series of questions about details of orders for prints placed by Fokine. Included here is information about the price of prints that varies according to the size and quality of the paper with 15 NOK for the most expensive and $5 \mathrm{NOK}$ for the cheapest. ${ }^{61}$ Via Balabanov, Eide also reassures Fokine that two specified photos have been destroyed. This indicates that Fokine used his artistic prerogative as choreographer to decide whether the finalized photos could be reproduced or not.

The letters fail to mention Vera Fokina's name even once; not even in the concluding greetings is she mentioned. Instead, Balabanov extends his good wishes to Fokine and an Igor Petrovich, who seems to have played a part in the tour of Fokina and the negotiations in Stavanger. ${ }^{62}$ While the letters show that the choreographer had a strong say, at least in the part of the photographic process that went on after the dancer had left the studio, they contain little

56. Risa 2016, 77.

57. Ibid.

58. Op. cit., 76 .

59. The terms in the Danish translation are 'præsentationer og optagelser'.

60. According to Sigrid Lien, Eide's Vera Fokina portfolio was announced for sale in Stavanger Aftenblad [Stavanger Evening Mail, 11 March 1919]. While the circulation number in the portfolios themselves is stated as 30 , the number given in the announcement is 80 (Lien 2016, 93).

61. The price of 10 NOK is used for cards for reproduction in journals and for advertisements.

62. Balabanov's letters repeatedly urge Fokine to return to perform in Stavanger. The post scriptum of the second letter mentions 20000 NOK deposited in the bank as a guarantee sum for 10 proposed performances in January 1920. The tour was never realized. 
to substantiate the claims of a co-creative relationship between model and photographer. I turn therefore to the photos from the Vera Fokina Portfolio themselves as reproduced in the catalogue from Stavanger Arts Museum. ${ }^{63}$ In most instances the ballerina is robed in costumes from the program of her solo tour, among these The Dance of the Seven Veils from Salome, The Caucasian Dance, The Russian Dance and The Dying Swan. A few of the photos, however, have no repertoire assigned and in one portrait she is in what seems to be her

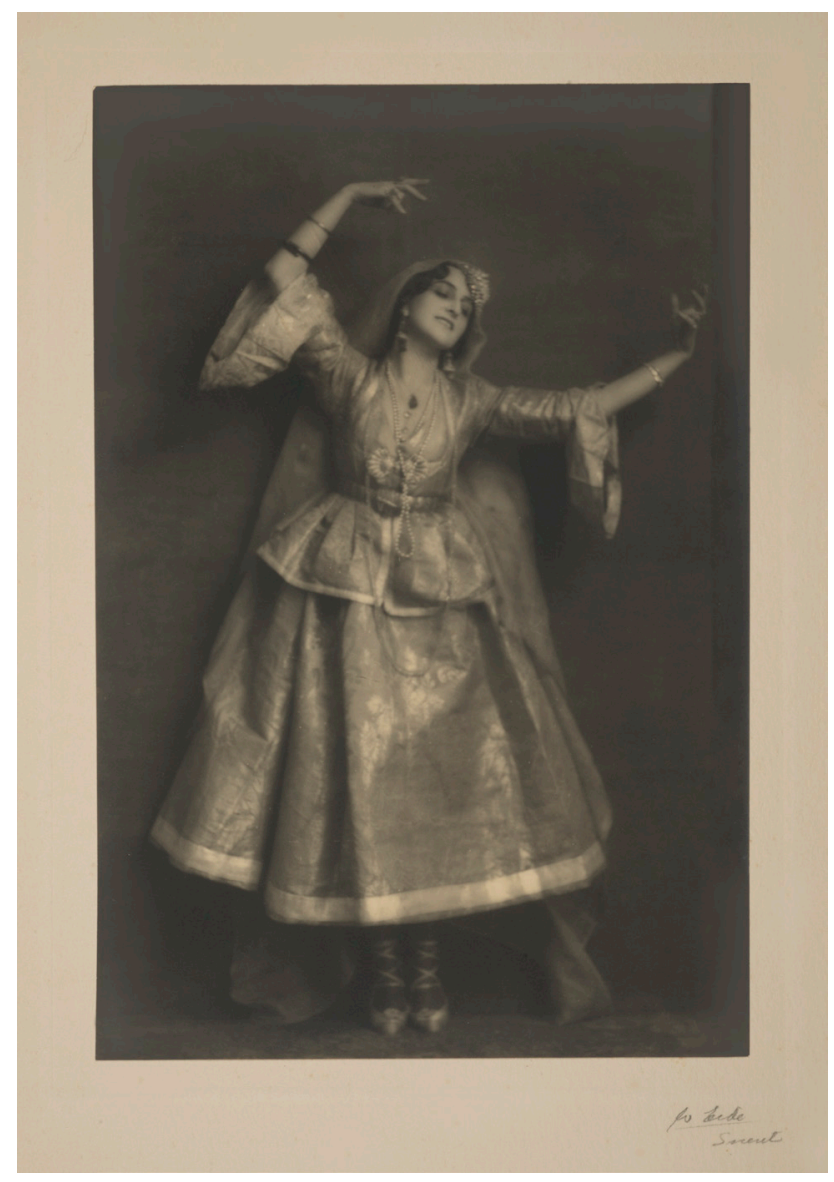

Figure 2. Vera Fokina (1919) The Caucasian Dance. The Vera Fokina Portfolio. Photo by Waldemar Eide, Stavanger Art Museum.

private attire. Regardless whether she has been shot in a dance pose, standing upright, or seated, Vera Fokina performs before the camera with an ease that communicates a corporeally grounded self-assurance. While her dancer-bodily being may be seen as idealized, it also comes across as an expression of will and a medium of action. Her gaze is, at times, oblique or flirtatious, at other times, more direct and earnest. Always, she seems confidently centred in her-

63. The reproduced photos were printed on silver gelatine in varying sizes from 155$175 \times 220-235 \mathrm{~mm}$. 
self. Hanne Holm-Johnsen positions Eide as a neo-pictorialist, e.g. belonging to the upswing in pictorialism following World War I characterized by simplified forms, stylized lines, and a focus kept on the model. ${ }^{64}$ Adding to this, my reading of the dancer's poses in these photos suggests that making space for the expressive intentions of the dancer-model was an integrated dimension in his studio practice.

The Vera Fokina portfolio was exhibited in, among other places, Stockholm, London, Copenhagen, and Los Angeles ${ }^{65}$ granting Eide an international name as a 'pictorial photographer', the term with which he used to describe himself in later years. ${ }^{66}$

In order to ascertain more precisely the contributions of the dancer to dance pictorialism, I now turn to the Swedish photographer Henry B. Goodwin's discussion of Eide's work in an essay in which he also reflects on his own collaboration with Fokine and Fokina.

\section{THE VERA FOKINA PORTFOLIO SEEN THROUGH THE LENS OF HENRY B. GOODWIN}

A brief survey of Nordisk Tidskrift för Fotografi from the years between 1917 and 1921 shows a substantial part of the contents to be focused on technical equipment and its operation, e.g. how to work with the diffusion of light. ${ }^{67}$ Another category of articles discusses details in film development, the use of chemicals in the print process and different qualities of paper. Interspersed between the discussion of various material practices of the trade, the journal features essays on the history of photography as well as a column entitled "Our Nordic colleagues". It is under this heading, the founder of the journal, Henry B. Goodwin, writes in advance of Eide's exhibition in Stockholm in the fall of 1919.68

Goodwin's portrait of his colleague revolves around a comparison between Eide's photos of Fokina and his own work with what he calls, "a series on dance and costumes with one of the most desirable models one could wish for, Vera Fokina." ${ }^{69}$ The reference is to a photo session in May 1918 when the Fokine couple had visited Goodwin's studio in connection with their performances at the Royal Swedish Opera. Two photos from this session, one showing Vera Fokina in the title role of Salome the other Mikhail Fokine as Perseus, are included in a small publication by Ida Goodwin and Henry B. Goodwin in

64. Holm-Johnsen 2016, 89-90.

65. Salthe 2016a, 124.

66. Risa 2016, 80.

67. In line with his pioneering role in Nordic photographic circles, Goodwin founded the journal Nordisk Tidskrift för Fotografi in 1916.

68. The exhibition took place at the Photographic Society's Scandinavian exhibition in October 1919. Goodwin's article about Eide is found in Nordisk Tidskrift för Fotografi. No. 30-31, June, July 1919.

69. Goodwin 1919, 82. My translation. 
honour of the Swedish dancer Jenny Hasselquist. ${ }^{70}$ Goodwin's comparison is telling from a socio-material perspective as it describes the preparations for the photo shoot that had taken almost a whole day and involved not only Vera Fokina and himself, but also their partners Mikhail Fokine and Ida Goodwin as well as the dresser and other assistants:

\begin{abstract}
Rarely has such a huge apparatus been set in motion in my home, so much space been needed, so many different lighting and optical devices been in use. The result, however, was meagre: from an inconceivable number of negatives and after more or less meticulous re-working, three, possibly four fully satisfactory pictures. [...] It was nothing beyond what could be expected given the skills of the model and oneself. ${ }^{71}$
\end{abstract}

The quote suggests that the bulk of Goodwin's work with Fokine and Fokina went on in the preparatory stages and before the camera rather than after the image had been imprinted on the negative. ${ }^{72}$ By way of explaining what he perceived as the inferiority of his own results, Goodwin suggests that Vera Fokina was in better shape on her Norwegian tour in 1919, and that also the costumes had been improved. ${ }^{73}$ It is quite possible that he is right, since the photos in Stavanger were taken in connection with Vera Fokina's solo tour for which she would have trained rigorously and the costumes most likely had been retouched. Goodwin also notes that the presence of the strongly opinionated Mikhail Fokine in his studio in Stockholm had been a considerable disturbing factor. ${ }^{74}$ However, the fact that Eide's portfolio contains a photo of Fokine in addition to 14 photos of Fokina suggests that the choreographer was also present in at least one of the studio sessions in Stavanger. Moreover, Balabanov's letters are a testimony to the choreographer's say in the final selection of photos for the portfolio.

Complementing the more general characterizations of pictorialist studio practices, the juxtaposition of information regarding Goodwin and Eide's work with the same model confirms the importance of the costumes, but no less of the dancer and, in the case of Fokina, also of the choreographer in the final result.

As already noted, Vera Fokina was not the only dancer trained in Fokine's style with whom Goodwin and Eide worked. I now turn my gaze to Goodwin's work with Jenny Hasselquist, the results of which were presented in an ex-

70. Goodwin and Goodwin 1918, plates XI and XII.

71. Goodwin 1919, 82-83. My translation.

72. A comparison of the published photos of Fokine and Fokina suggests that Goodwin's pictures were processed using different techniques and with less care for the delicate balance of light and shadows than Eide's. This, however, cannot be verified unless a comparison is made between the original photos by someone with expertise in the darkroom practices used.

73. Salthe 2016a, 124 .

74. Op.cit. 83. 
hibition in Copenhagen in April 1918 that included a series of twenty dance studies. Taken in the period 1916 -18 Goodwin's photos of Jenny Hasselquist in Fokina's roles from Les Sylphides, Salome, Le Carnaval, and The Dying Swan also contribute the bulk of the illustrations in the tributary publication to the Swedish dancer from 1918, where they accompany the text by Ida Goodwin. ${ }^{75}$ Based on personal impressions of Hasselquist, her essay includes detailed observations that confirm the dancer's precise command of her composure before the camera. Recalling the change that took place in Hasselquist when she entered the studio, Ida Goodwin writes:

Now Jenny Hasselquist was fully present, the face lit up, became alive, she was attentive, elastic in every fiber of the body. The movement of the arms vibrated into the sensitive fingers [...], the flexion of the muscles yielded reflexes of light on the white surface of the silk tricot, the gauze dress [...] followed the body entirely, it opened up like a fan, puffed up like a bird of paradise [...]. Now and then it gained the contours of a white azalea flower. ${ }^{76}$

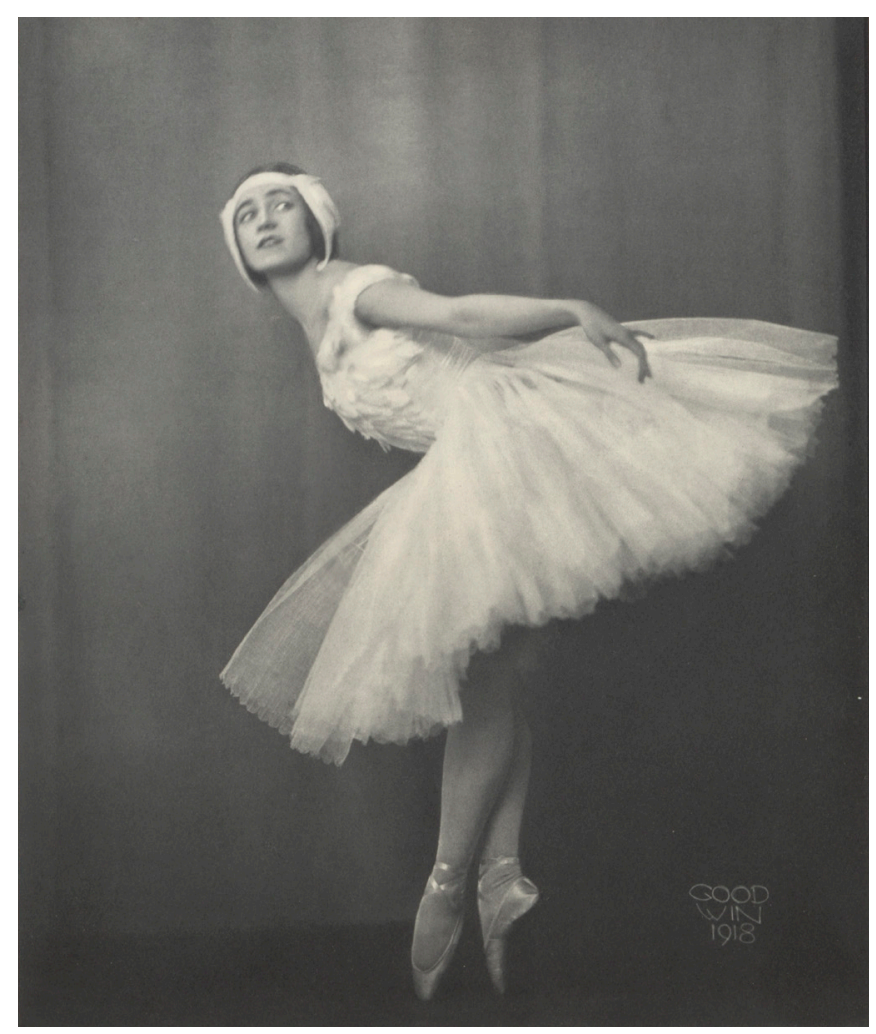

Figure 3. Jenny Hasselquist, The Dying Swan. Photo by Henry B. Goodwin from a series of photos of Hasselquist taken between 1916 and 1918. The Goodwin Collection, The Royal Swedish Library.

75. Ida Goodwin and Henry B. Goodwin 1918.

76. Op.cit., 20-21. My translation. 
The quote shows how Hasselquist's transformation from a self-effacing young woman to an effervescent ballerina, whose mental powers, precise movements and control of her limbs made her sparkle before the camera, left a strong impression on Ida Goodwin. Even more notably, the pose described at the end of the quote was captured by Goodwin's lens, published together with other photos in the printed media and ultimately re-produced in a painting by Harald Giersing.

\section{HARALD GIERSING'S DANCE PHOTOGRAPHY PAINTINGS}

Pictorialism looked to art history for inspiration in terms of composition, techniques for working with the negative, the print, as well as the presentational formats. The Danish modernist painter Harald Giersing reciprocated the gesture by looking to contemporary photography in several of his works. ${ }^{77}$ Among these are two cubist inspired paintings from 1918 both of which are based on emblematic photos from Fokine's repertoire: I have identified the template the painting entitled Fokin and Fokina ${ }^{78}$, which shows the couple in Le Carnaval, as one of the photos from Atelier Jaeger in 1913. The other entitled The Dancer, ${ }^{79}$ reproduces the aforementioned photo by Goodwin of Jenny Hasselquist as The Dying Swan. ${ }^{80}$ Giersing would have had the possibility of seeing this work either in Goodwin's exhibition in Copenhagen the same year, or in one among several reproductions in the printed media, for example the ladies' journal Vore Damer, where it was featured as part of the pre-announcement of the upcoming season with Fokine's repertoire danced by the Royal Swedish Opera ballet in Tivoli in the summer of $1918 .{ }^{81}$

In his transposition of the photographic images to paintings, Giersing detracts the sentimental and enigmatic qualities associated with pictorialism, such as the hazy borders of the motifs, the delicate balancing of light on skin and costume, and the foggy depths of the images. Left are the stylized motifs accentuated by colour, shape, and movement. Hasselquist's tulle skirt is in The Dancer transformed into a circular shape of pink petals that would entirely dissolve the dancer were it not for the flickering arms that open to the sides against a blue background. As suggested by museum curator Ole Jul in a presentation of the painting on the webpage of Kunstmuseum Sønderjylland, what is left is a two-dimensional abstraction, the blades of which, in a futurist reading, may be seen to belong to a powerful centrifugal device. ${ }^{82}$

77. Gottlieb 1981, 14.

78. Harald Giersing, 1918a. Fokin og Fokina. Oil on compoboard, $150 \times 115 \mathrm{~cm}$. Ibid.

79. Harald Giersing, 1918b. Danserinde. Oil on compoboard, $122 \times 90 \mathrm{~cm}$. Ibid.

80. Giersing's photo is on the cover of En anden Dans (2008). On p. 2, I wrongly identify the model of the photographic template for Giersing's picture as Vera Fokina. Upon finding the photo of Jenny Hasselquist, I corrected this and also informed Ole Jul, Sønderjyllands Kunstmuseum.

81. Vedel 2008, 171-77.

82. Jul 2003. Webpage of Museum Sønderjylland. 




Figure 4. The Dancer (1918). Painting by Harald Giersing based on a photo by Henry B. Goodwin showing Jenny Hasselquist as the Dying Swan: Courtesy of Sønderjyllands Art Museum.

Rancière, in his discussion of scenes from the aesthetic regime, draws attention to the dismantling of the rules and norms of the representations of the body in both dance, photography, and painting. ${ }^{83}$ In place of a unified harmonious body, he claims, the aesthetic regime saw new figures emerge, in which the body appeared as 'fragmented' and its forces 'redistributed'. ${ }^{84}$ I cannot help but notice the similarities between the disappearance of the dancer into futurist abstraction in Giersing's painting and what Rancière, with a loan from Georges Rodenbach, calls Loïe Fuller's 'unlocatable body' in the swirling garments of her dance. ${ }^{85}$

\section{CONCLUSION}

My conclusion links several propositions. With dance history, I argue that a certain emancipatory authority may be ascribed to the reformed Russian ballet, its female practitioners, and their corporeal representation in pictorialist photography. In continuation, I observe that the selected dance photos communicate a materiality that relies more on the dancer's command of her corporeal presence than has hitherto been acknowledged. Thirdly, considering the transposition of the motifs from Fokine's repertoire from one dancer, one photographic

83. Op. cit. pass., 207-24.

84. Rancière 2013, 104.

85. Op. cit. 97, 105 and 108. 
studio, and one publication to another, I conclude that dance pictorialism made a considerable contribution to the production and circulation of new visual and corporeal schemas that had implications not only for Fokine's enterprise, but also for the visual representation of the female dancing body.

The larger argument challenges the common understanding of the defining operations of pictorialism to take place after the shutter has clicked. Rather, based on the social-material approach to the studio sessions with Fokina and Hasselquist, my paper suggests that while there was not full control over the final image on the dancer's side, the performance before the camera, which I perceive to reflect an understanding of the efficacy of the medium, granted the dancer's co-creative agency. Thus, my reading sees the role of Vera Fokina and Russified dancers before the camera as an integrative part of the material practices of pictorialist photography.

According to Rancière, when Stieglitz's work became perceived as art, it was because they owed nothing "either to the quality of their subject or to any artistic addition meant to raise them from their mediocrity." ${ }^{86}$ My findings show something different. They suggest that the figures of the body emerging after the dismantling of the classical norms of representation of the body were indebted to dance pictorialism. In this sense, the gesture that Giersing's painting completes was initiated already in the energetic pose with which Hasselquist presented her Dying Swan to Goodwin's camera. It became imbued with new meaning within the symbolic system of photography and was widely circulated alongside a number of other dance photos from the studio sessions discussed in my paper. Thus, in ever-continuing processes of meaning production, exchange and usage, the photos took on an agency of their own. They performed.

\section{ACKNOWLEDGMENTS}

I am grateful to Vibece Salthe, Curator, Stavanger Kunstmuseum for generously responding to questions about the Vera Fokina Portfolio, Matthew Whittman, The Harvard Theatre Collection for help with retrieving Balabanov's letters and to theatre scholar, Associate Professor Annelis Kuhlmann, Aarhus University for their translation of the letters from Russian to Danish. I also thank the anonymous readers for their most useful suggestions.

86. Rancière 2013, 209. 


\section{References}

Aftonbladet 18.09.1918. "Dansfantasi av M Fokin 800 medverkande".

Alter, Judith B. 1994. Dancing and Mixed Media. Early Twentieth-Century Modern Dance Theory in Text and Photography. New York: Peter Lang Verlag.

Armstrong, Nancy. 1998. "Modernism's Iconophobia and What it Did to Gender." Modernism/Modernity, vol. 5 no. 2, 1998, 47-75.

Barthes, Roland. 2000. Camera Lucida. Reflections on Photography. London: Vintage Books.

Beaumont, Cyril W. 1996 (1935). Michel Fokine and his Ballets. London: Dance Books.

Bennett, Jane. 2010. Vibrant Matter. A Political Ecology of Things. Durham: Duke University Press.

Carbonneau, Suzanne. 1998. "Michel Fokine". In Selma Jeanne Cohen (ed.): International Encyclopedia of Dance. Vol 3. New York: Oxford University Press. 14-28.

Deranty, Jean-Philippe. 2013. "The Symbolic and the Material: A Review of Jacques Rancière's Aisthesis: Scenes from the Aesthetic Regime of Art" (Verso 2013). In Parrhesia. No. 18. 2013. 139-144.

Edwards, Elizabeth. 2009. "Photography and the Material Performance of the Past". History and Theory. Theme Issue 48. (December 2009). 130-150.

Edwards, Elizabeth. 2002. "Material beings: objecthood and ethnographic photographs". In Visual Studies, 17:1. 67-75.

Ewing, William A. 1987. The Fugitive Gesture: Masterpieces of Dance Photography. New York: Peter Lang.

Garafola, Lynn. 1989. Diaghilev’s Ballets Russes. New York. Oxford: Oxford University Press.

Goodwin, Henry B. 1919. "Kolleger världen rundt. XIV. Waldemar Eide. Stavanger". Nordisk Tidskrift för fotografi. No. 30-31 June-July 1919. 81- 84.

Goodwin, Ida and Henry B. Goodwin. 1918. Jenny Hasselqvist. Publikens Gunstlingar III. Stockholm: Lars Hökerbergs Förlag.

Gottlieb, Lennart. 1981. Portrætter og figurbilleder af Harald Giersing 18811927. København: Statens Museum for Kunst. 
Holm-Johnsen, Hanne. 2016. "Waldemar Eide and Pictorialism". In Vibece Salthe (ed.). Waldemar Eide. Kamerakunst. Stavanger: Stavanger Kunstmuseum. 87-92.

Jul, Ole. 2003. Månedens billede. April 2003. Webpage of Museum Sønderjylland. (15 September 2017)

Lien, Sigrid. 2016. "Ballerinaen i fotografens studio. Waldemar Eides fotografier av Vera Fokina". In Vibece Salthe (ed.). Waldemar Eide. Kamerakunst. Stavanger: Stavanger Kunstmuseum. 93-99.

Rancière, Jacques. 2013. Aiesthesis. Scenes from the Aesthetic Regime of Art. Verso.

Risa, Lisabet. 2016. “Waldemar Eide 1886 -1963”. In Vibece Salthe (ed.). Waldemar Eide. Kamerakunst. Stavanger: Stavanger Kunstmuseum. 73-80.

Rootzén, Kajsa. 1945. Den svenska baletten: Från Stiernhielm till Brita Appelgren.

Salthe, Vibece (ed.). 2016a. Waldemar Eide. Kamerakunst. Stavanger: Stavanger Kunstmuseum.

Salthe, Vibece. 2016b. "Waldemar Eide - Photography as Art". In Vibece Salthe (ed.). Waldemar Eide. Kamerakunst. Stavanger: Stavanger Kunstmuseum. 8186.

Swedlund, Charles. 1974. Photography. A Handbook of History, Materials, and Processes. Tennessee: Holt, Rinehart and Winston, Inc.

Söderberg, Rolf and Pär Rittsel. 1983. Den svenska fotografins historia, 18401940. Stockholm: Bonnier Fakta.

Söderberg, Rolf. 1988. "Pictorialist and Portraitist. Introduction". Henry B. Goodwin. Pictorialist och porträttör. Pictorialist and Portraitist. Scandinavian Photographers Classic and Contemporary. Laholm: Alfabeta Bokförlag.

Toepfer, Karl. 1997. Empire of Ecstasy, Nudity and Movement in German Body Culture 1910 - 1935. Berkeley: University of California Press.

Vedel, Karen. 2008. En anden dans. Moderne scenisk dans i Danmark 1900 1975. København: Multivers. 


\section{ARCHIVAL MATERIAL}

Contract signed by Mikhail Fokine and Fr. Brockenhuus Schack, Director, The Royal Danish Theater, 25 April, 1918, Theatre Journal 71/1918, The Danish National Archives.

Det Kongelige Teater. Letter (s.n.) addressed to Mikhail Fokine. Theatre Journal 71/1918, The Danish National Archives.

Balabanov, Eugene E. 1919. Three letters to Michel Fokine, 1919. In Fokine, Michel, 1880-1942. Michel Fokine Papers. Series: II. Correspondence (9). Houghton Library, Harvard Library, Harvard University. http://oasis.lib.harvard.edu/ oasis/deliver/ hou00221 (15 September 2017).

Michel Fokine and Vera Fokina. List of performances. Tss, 1918-1928. 1 folder. Series: III. Biographical material (40). Fokine, Michel, 1880-1942. Michel Fokine Papers. Houghton Library, Harvard Library, Harvard University. http://oasis.lib. harvard.edu/oasis/deliver/ hou00221 (15 September 2017).

Stureson (on behalf of Mikhail Fokine). 1918. Telegram addressed to The Royal Danish Theatre. The National Archive. The Royal Theatre. Incoming documents nr. 55. 1918.

\section{PHOTOGRAPHS AND ART WORKS}

En Nat i AEgypten. 1918. Anon. The photo archives of the Royal Theatre Archives and Library.

Giersing, Harald. 1918. Danserinde. Colour postcard. Original in Museum Sønderjylland. Oil on compoboard; 122 x $91 \mathrm{~cm}$. http://www.museumsonderjylland.dk/SIDERNE/Museerne/Kunst-Tonder/04c09-April2003.html (15 September 2017).

Giersing, Harald. 1918. Fokin og Fokina. Oil on compoboard; 150 x $115 \mathrm{~cm}$. In Lennart Gottlieb. 1981. Portrætter og figurbilleder af Harald Giersing 18811927. København: Statens Museum for Kunst.

Goodwin, Henry B. 1918. Jenny Hasselquist as The Dying Swan. In Vore Damer, April 2018.

Goodwin, Henry B. 1918a. Salome. Plate XI. Perseus. Plate XII. In Ida Goodwin and Henry B. Goodwin. Jenny Hasselqvist. Publikens Gunstlingar III. Stockholm: Lars Hökerbergs Förlag. 


\section{ONLINE RESOURCES}

Royal Swedish Opera Archives https://www.operan.se/arkivet/ (15 September 2017).

DIGI, Nationabibliotekets Digitala Samlingar. https://digi.kansalliskirjasto.fi (15 September 2017).

Svenska Dagstidningar online. http://tidningar.kb.se (15 September 2017).

\section{AUTHOR}

Karen Vedel, Associate Professor, PhD, Theatre and Performance Studies, Department of Arts and Cultural Studies, University of Copenhagen. Research areas include dance and theatre historiography, site specificity and cultural memory. Has since 1998 collaborated extensively in projects involving dance artists and scholars in the Nordic countries and South Africa. Author of among other titles "Corporeal Aesthetics and the Reception of African American Performing Arts around 1930" in Tania Ørum et al. (eds): A Cultural History of the Avant-Garde in the Nordic Countries 1925 - 1950. (Harrassovitz, in press). "Nordic Dance Spaces. Imagining and Practicing a Region" (editor and contributing author) (Ashgate, 2014). "Clothing the Suomussalmi Silent People. From Site Specific Performance to Ritually Informed Performative Event" in Christiane Brosius et al. (eds): Ritual Dynamics and the Science of Ritual. Reflexivity, Media, and Visuality (Harrassovitz, 2009). Project manager of the network "Knowledge Production, Archives and Artistic Research" (2016 - ). 